\title{
ALLICIN DIVERSITY IN SOME WILD POPULATION OF SIX ALLIUM SPECIES FROM IRAN
}

\author{
MAHBOOBEH ZARE MEHRJERDI ${ }^{1 *}$, MAHDI MORIDI FARIMANI ${ }^{2}$, JALAL REZAEI ${ }^{1}$, \\ HASSAN MASTALI ${ }^{1}$
}

${ }^{1}$ Department of Horticulture, Aburaihan Campus, University of Tehran, Tehran, Iran

${ }^{2}$ Department of Phytochemistry, Medicinal Plants and Drug Research Institute, Shahid Beheshti University, Tehran, Iran

*corresponding author: mzarem@ut.ac.ir

Manuscript received: August 2019

\begin{abstract}
Allium is a large genus of flowering plants with potential medicinal values. In this study, the potential use of wild Allium species as medicinal plants was evaluated by determining the allicin diversity in nine Allium populations from six species of subgenus Melanocrommyum sect., Acanthoprason and Asteroprason. The assessments involved HPLC analysis. In addition, the fresh weight of bulbs and the allicin yield of each population were examined. The results showed that allicin ranged from $4.82 \%$ to $17.55 \%$ in the bulbs of different populations. Such amounts of allicin are higher than the British pharmacopoeia level. The average of bulb fresh weight and allicin yield varied from $2.08 \mathrm{~g}$ to $4.85 \mathrm{~g}$ and from $0.20 \mathrm{~g}$ to $0.81 \mathrm{~g}$, respectively. Cluster analysis by the UPGMA method led to the classification of the nine wild populations of Allium into three major clusters. The study of diversity here provides a basis for future utilization of genetic resources in these populations and for their breeding.
\end{abstract}

\section{Rezumat}

Allium este un gen mare de plante cu flori, cu potențiale utilizări medicinale. În acest studiu, utilizarea potențială a speciilor sălbatice de Allium ca plante medicinale a fost evaluată prin determinarea diversității de alicină la nouă populații de Allium din şase specii din subgenurile Melanocrommyum sect. Acanthoprason şi Asteroprason. Evaluările au implicat analiza HPLC. În plus, s-a determinat greutatea proaspătă a bulbilor și randamentul de alicină pentru fiecare populație. Rezultatele au arătat că alicina a variat de la 4,82\% la 17,55\% în bulbul diferitelor populații. Aceste cantități de alicină sunt mai mari decât nivelul stipulat în Farmacopeea Britanică. Media de greutate a bulbului proaspăt şi randamentul de alicină a variat de la 2,08 g la $4,85 \mathrm{~g}$, respectiv de la $0,20 \mathrm{~g}$ la $0,81 \mathrm{~g}$. Analiza clusterului prin metoda UPGMA a condus la clasificarea celor nouă populații sălbatice de Allium în trei grupe majore. Studiul oferă o bază pentru utilizarea viitoare a resurselor genetice din aceste populații și pentru reproducerea lor.

Keywords: allicin, Allium, diversity, Melanocrommyum

\section{Introduction}

Medicinal plants have received considerable attention since ancient times due to their therapeutic properties. They are widely used for treating diseases. Further to the long history of medicinal plants and their usage, most medicinal plants are still being harvested from the wild. Nearly 15,000 species of wild harvested medicinal plants are now at the impending risk of extinction as a result of overharvesting, population decline and the destruction of their natural habitats [11]. Fluctuations in quality and quantity of secondary metabolites, along with a loss of genetic diversity, are characteristic of medicinal plants that are harvested from their natural habitats. The conservation, domestication and cultivation of medicinal plants can serve as effective solutions and appropriate responses to the increasing demand for phytomedicines.

Cancer, cardiovascular disease, stroke and diabetes are among the top 10 causes of death across the globe
[34]. They have been the cause of death for more than 25 million people in 2015 [34]. Many cases of research have indicated that Allium species are effective in the prevention of those diseases $[1,6,9,12$, $13,15,23,28-31,37]$. In addition, Allium species are known to have antioxidant, anti-inflammation, antimicrobial and anti-obesity properties $[3,8,16,19,21$, 22, 26, 27, 32, 35]. The therapeutic effects of Allium are mostly attributed to sulphur compounds, especially allicin [7, 24]. Allicin is responsible for the specific aroma of Allium species. It is produced by the reaction of alliinase with alliin [10]. The amounts of allicin in Allium species are variable due to genetic and environmental factors. Allicin has beneficial effects that can contribute to the cure of human diseases. Accordingly, it can generate useful applications in medicine. In fact, allicin contents have been evaluated in the genetic resources of Allium species in previous research [5, 25, 33]. 
Iran is a central location of Allium diversity. It is home to several Allium species that are distributed across its natural reserves [14]. These species have received more attention as understood in the increasing number of studies on the numerous benefits of Allium species on human health, as well as a higher level of attention given to germplasm conservation over the past several years. Fristch and Abbasi [14] published a taxonomical review of the Allium subgenus Melanocrommyum in Iran. Furthermore, various studies have been conducted regarding the morphological, cytogenetic, molecular and phytochemical diversity of native Allium species $[2,4,17,18,20,36]$.

The current study aimed to determine allicin diversity in nine Allium populations from six species of the subgenus Melanocrommyum sect. Acanthoprason and Asteroprason. The ultimate objective is to provide useful information for a better exploitation, conservation and breeding of these valuable medicinal plants.

\section{Materials and Methods}

\section{Plant material}

Nine Allium populations were collected from the wild. In total, they were identified as six species of subgenus Melanocrommyum sect. Acanthoprason and Asteroprason. The populations were from different habitats in Iran according to Fritsch and Abbasi [14]. Randomly, ten bulbs with two replications were used in each population. All samples were collected at the flowering stage, weighed and frozen in liquid nitrogen immediately after harvesting. They were stored at $-80^{\circ} \mathrm{C}$. The species of samples and the sites from which they were collected are listed in Table I.

Allium species and collection sites of nine natural Allium populations belonging to six species of subgenus Melanocrommyum sect. Acanthoprason and Asteroprason included in the analysis

\begin{tabular}{|c|c|c|c|c|c|c|}
\hline $\begin{array}{l}\text { Pop. } \\
\text { no. }\end{array}$ & Section & Species & Location (Province) & $\begin{array}{c}\text { Latitude } \\
(\mathrm{N})\end{array}$ & $\begin{array}{l}\text { Longitude } \\
\text { (E) }\end{array}$ & $\begin{array}{c}\text { Altitude } \\
\text { (m) }\end{array}$ \\
\hline 1 & Asteroprason & A. elburzanse & Ghabre Oros (Tehran) & $51618^{\circ} 35$ & $2525^{\circ} 51$ & 2821 \\
\hline 2 & Asteroprason & A. elburzanse & Kandovan Tunnel (Mazandaran) & $956^{\circ} 36$ & '19 $16^{\circ} 51$ & 2672 \\
\hline 3 & Asteroprason & A. pseudobodeanum & Shen Jari (Tehran) & $450^{\circ} 35$ & $50372^{\circ} 52$ & 2290 \\
\hline 4 & Acanthoprason & A. derderianum & Vali Abad (Mazandaran) & $18856^{\circ} 36$ & $111^{\circ} 51$ & 2421 \\
\hline 5 & Acanthoprason & A. derderianum & Kochka (Mazandaran) & $18232^{\circ} 36$ & $0453^{\circ} 51$ & 2248 \\
\hline 6 & Acanthoprason & A. derderianum & Vandarin (Mazandaran) & $2255^{\circ} 36$ & $141^{\circ} 51$ & 2926 \\
\hline 7 & Acanthoprason & A. kurdistanicum & Taze Abad Oryeh (Kurdistan) & $.742^{\circ} 35$ & $40309^{\circ} 47$ & 2332 \\
\hline 8 & Acanthoprason & A. minutiflorum & Dehdasht (Kohgiluyeh and Boyer-Ahmad) & '50 $315^{\circ} 30$ & $33067^{\circ} 50$ & 1920 \\
\hline 9 & Acanthoprason & A. subakaka & Jame Shoran (Kurdistan) & $\cdot 5733^{\circ} 35$ & $39175^{\circ} 47$ & 2318 \\
\hline
\end{tabular}

\section{Determining the allicin content}

Allicin content was measured according to a method previously used by Baghalian et al. [5]. Accordingly, $20 \mathrm{~mL}$ of distilled water was added to $800 \mathrm{mg}$ of bulb powder which was obtained from each sample. This solution was placed in an ultrasonic bath at $4^{\circ} \mathrm{C}$ for $5 \mathrm{~min}$. The homogenates were incubated for $30 \mathrm{~min}$ at room temperature and subsequently centrifuged at $6000 \mathrm{~g}$ for $30 \mathrm{~min}$. Then, $10 \mathrm{~mL}$ of the supernatant was added to the vial containing $15 \mathrm{~mL}$ of A mix $(1 \%(\mathrm{v} / \mathrm{v})$ solution of anhydrous formic acid and methanol (4:6)). This was centrifuged again at $6000 \mathrm{~g}$ for $5 \mathrm{~min}$. The extracts were analysed promptly following the extraction. $20 \mathrm{mg}$ of butyl parahydroxybenzoate was dissolved in $100 \mathrm{~mL}$ of methanol:water (50:50) for use as an internal standard. Then, $0.5 \mathrm{~mL}$ of the internal standard was added to $9.5 \mathrm{~mL}$ of the supernatant. A sample volume of $20 \mu \mathrm{L}$ was injected into the HPLC. The analyses were performed with a Knauer HPLC system (Berlin, Germany) equipped with a Knauer C18 column $(25 \mathrm{~cm} \times 4.6 \mathrm{~mm})$ and a PDA detector. The mobile phase comprised methanol:water (50:50) and was characterized by a flow rate of $0.7 \mathrm{~mL} / \mathrm{min}$. The detection was carried out at $254 \mathrm{~nm}$. Finally, the following formula was set to calculate the percentage of allicin:

$$
\text { Allicin }(\%)=\frac{\mathrm{s}_{1} \mathrm{~m}_{2} * 22.75}{\mathrm{~s}_{2} \mathrm{~m}_{1}},
$$

where $s_{1}$ and $s_{2}$ are the area of the peak corresponding to allicin and the internal standard, $\mathrm{m}_{1}$ and $\mathrm{m}_{2}$ represent the mass of the Allium powder and the butyl parahydroxybenzoate in the internal standard solution, respectively.

The mean value of allicin yield in each population (per plant) was calculated by using the average of allicin (\%) and the average of bulb fresh weight. The "Gorgan" garlic ecotype was used as the control because of its high allicin content (according to Baghalian et al. [5]). Statistics

A Pearson correlation was used for determining the correlations between allicin content and bulb fresh weight. The cluster analysis of populations was carried out based on the allicin content and the bulb fresh weight using the un-weighted pair group method with arithmetic averages (UPGMA). The statistical analyse of data were performed using the SPSS statistical programme (SPSS Inc., Chicago, USA).

\section{Results and Discussion}

The evaluation of allicin content by HPLC (Figure 1) revealed that there were differences between populations in terms of their bulb allicin content, ranging from 
$4.82 \%$ in A. derderianum (Vandarin population) to $17.55 \%$ in A. kurdistanicum (Taze Abad Oryeh population). The allicin contents of all populations are provided in Figure 2.

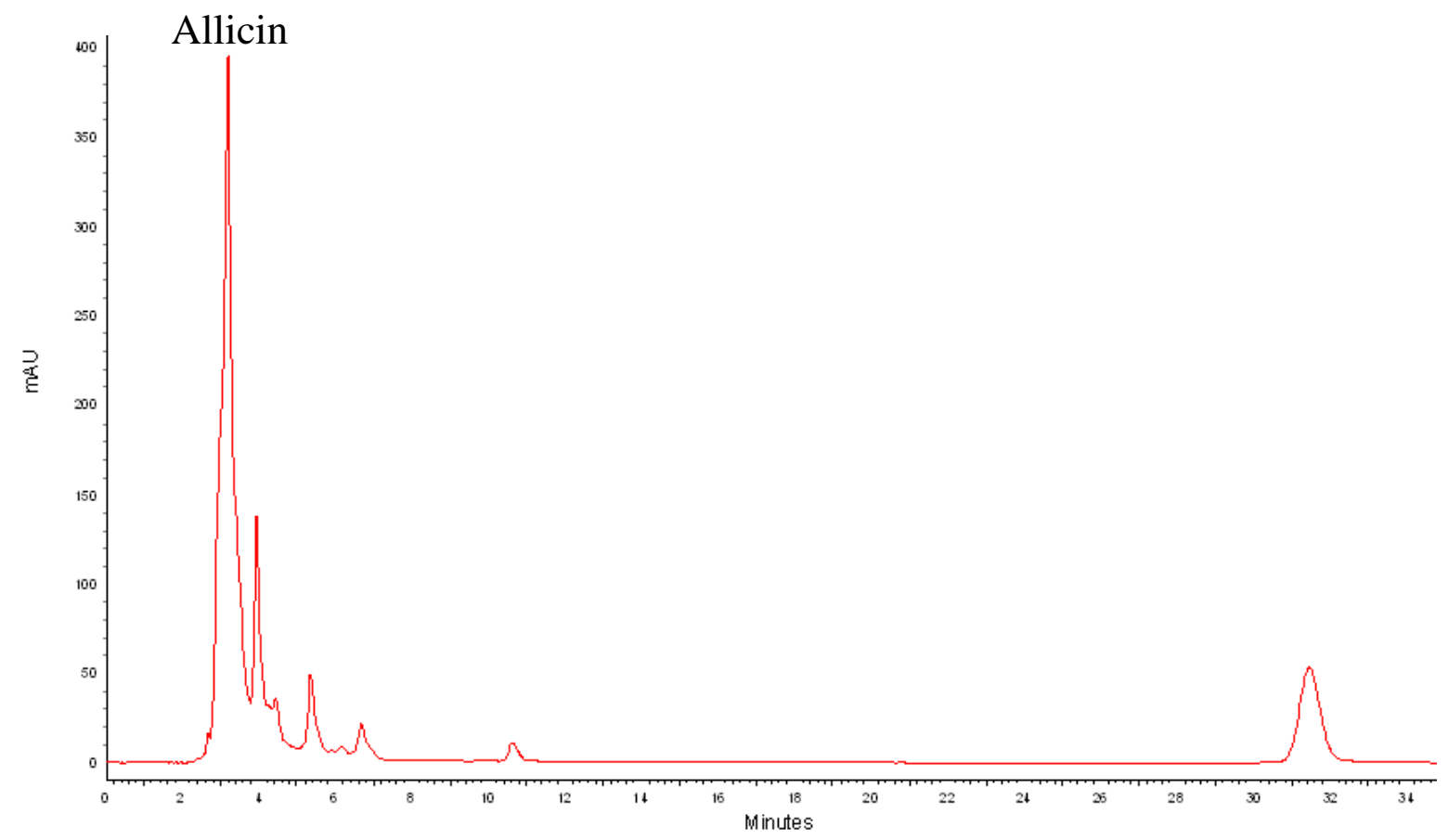

Figure 1.

HPLC chromatogram of allicin in test sample

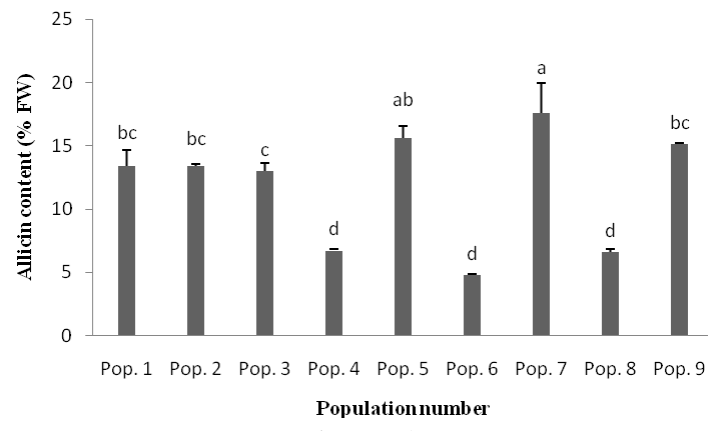

Figure 2.

Representation of the measured allicin content of bulbs of nine natural Allium populations from Iran. Bars are means \pm SD.

Apparently, each and every population has an allicin content that is higher than the British pharmacopoeia level $(0.45 \%)$ and, in some cases, they surpassed the percentage of allicin recorded in genotypes and ecotypes of garlic in different countries [5, 25, 33] and in the Gorgan garlic ecotype $(9.11 \%)$ which was used as the control. Accordingly, all nine populations can be deemed suitable for the pharmacy industry. Variations in the allicin content of samples can be explained by genetic and environmental factors. Such reasons for variation are consistent with the results of previous studies [5, 25, 33]. The bulb fresh weight is also influenced by genetic and environmental factors.

The average of bulb fresh weight in the nine populations varied from $2.08 \mathrm{~g}$ in Ghabre Oros (A. elburzanse) to $4.85 \mathrm{~g}$ in Jame Shoran population (A. subakaka) (Figure 3). In this regard, the available literature cites variations in bulb fresh weight in previous works on Allium [18, 33].

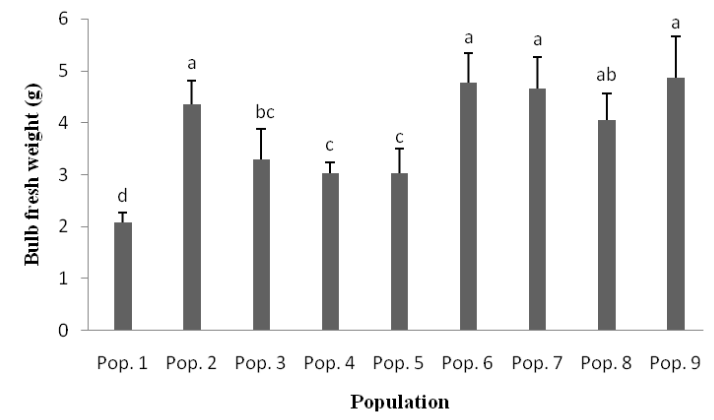

Figure 3.

Average of bulb fresh weight of nine natural Allium populations from Iran. Bars are means \pm SD.

No correlation was found between allicin content and bulb fresh weight. Due to the variations in bulb weight, the allicin yield was calculated in order to determine the potential of each population for allicin production.

The allicin yield of bulbs in each population (Figure 4) revealed that the Taze Abad Oryeh (A. kurdistanicum) and Vali Abad (A. derderianum) populations had the highest $(0.81 \mathrm{~g})$ and the lowest $(0.20 \mathrm{~g})$ average of allicin yield of bulbs, respectively. 


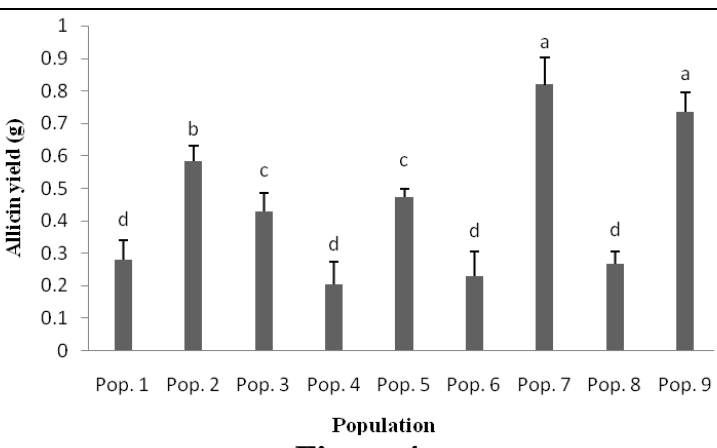

Figure 4.

The average of bulb allicin yield of nine natural Allium populations from Iran. Bars are means \pm SD.

Cluster analysis grouped the nine wild populations of Allium into three major clusters. Each cluster hosted three populations (Figure 5). The first cluster consisted of two sub clusters including Kandovan Tunnel ( $A$. elburzanse), Taze Abad Oryeh (A. kurdistanicum) and Jame Shoran (A. subakaka) populations. The second major cluster of the dendrogram comprised two subclusters, including Shen Jari (A. pseudobodeanum), Kochka (A. derderianum) and Ghabre Oros (A. elburzanse) populations. Vandarin (A. derderianum), Dehdasht (A. minutiflorum) and Vali Abad (A. derderianum) populations were grouped in cluster III. However, clustering could not completely separate the populations based on species and geographical origins.

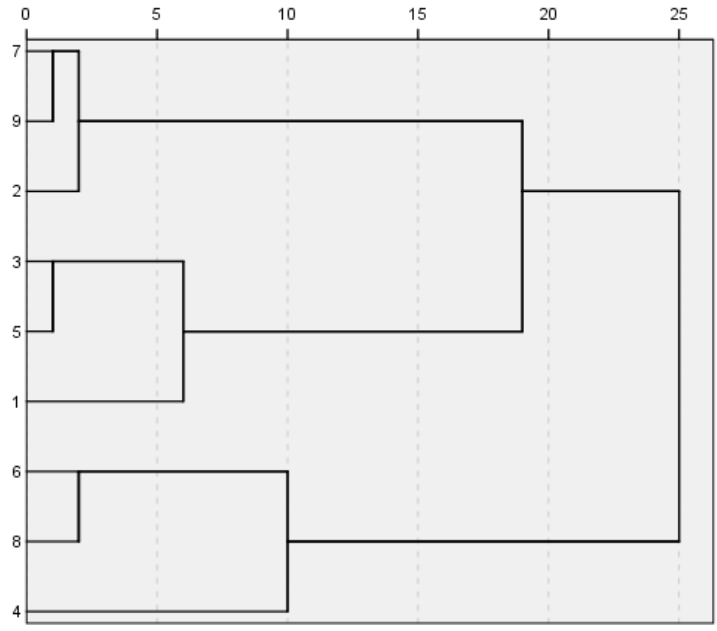

Figure 5.

Dendrogram obtained by cluster analysis of nine natural Allium populations from Iran using UPGMA method.

\section{Conclusions}

Allicin is a major compound in the genus Allium, especially in A. sativum, and most of the benefits that are attributed to garlic usually emanate from this metabolite. In this study, allicin yield was evaluated in some wild relatives of garlic. The results indicated that these populations have notable allicin content. Two populations of different species from the Kurdistan province of Iran (Taze Abad Oryeh and Jame Shoran) had the highest allicin amounts and can be used as an alternative to garlic in future applications of medicinal research. The conservation, evaluation and breeding of wild crop relatives not only provide a great opportunity to exploit their therapeutic benefits but also play an important role in the genetic improvement of their domesticated counterparts in cultivation. The study of diversity reported herein provides a basis for the future exploitation of genetic resources in these populations.

\section{Acknowledgement}

The work was funded by the Iran National Science Foundation (INSF) and the author would like to thank the INSF for this support.

\section{Conflict of interest}

The authors declare no conflict of interest.

\section{References}

1. Akash MSH, Rehman K, Chen S, Spice plant Allium cepa: Dietary supplement for treatment of type 2 diabetes mellitus. Nutrition, 2014; 30(10): 1128-1137.

2. Akhavan A, Saeidi H, Zarre SH, Rahiminejad MR, Chromosome numbers and karyotype features of selected species of Allium L. (Amaryllidaceae) sect. Acanthoprason in Iran. Iran J Bot., 2015; 21(2): 158-164.

3. Arreola R, Quintero-Fabian S, Lopez-Roa RI, FloresGutierrez EO, Reyes-Grajeda JP, Carrera-Quintanar L, Ortuno-Sahagun D, Immunomodulation and antiinflammatory effects of garlic compounds. J Immunol Res., 2015; 2015: 1-13.

4. Aryakia E, Karimi HR, Naghavi MR, Fazeli SAS, Morphological characterization of intra-and interspecific diversity in some Iranian wild Allium species. Euphytica, 2016; 211(2): 185-200.

5. Baghalian K, Ziai SA, Naghavi MR, Badi HN, Khalighi A, Evaluation of allicin content and botanical traits in Iranian garlic (Allium sativum L.) ecotypes. Sci Hort., 2005; 103(2): 155-166.

6. Banerjee SK, Maulik SK, Effect of garlic on cardiovascular disorders: a review. Nutr J., 2002; 1(1): 1-14.

7. Bayan L, Koulivand PH, Gorji A, Garlic: a review of potential therapeutic effects. Avicenna J Phytomed., 2014; 4(1): 1-14.

8. Benkeblia N, Free-radical scavenging capacity and antioxidant properties of some selected onions (Allium cepa L.) and garlic (Allium sativum L.) extracts. Braz. Arch Biol Technol., 2005; 48(5): 753-759.

9. Bianchini F, Vainio H, Allium vegetables and organosulfur compounds: do they help prevent cancer? Environ Health Perspect., 2001; 109(9): 893-902.

10. Borlinghaus J, Albrecht F, Gruhlke MCH, Nwachukwu ID, Slusarenko AJ, Allicin: chemistry and biological properties. Molecules, 2014; 19(8): 12591-12618.

11. Chen SL, Yu H, Luo HM, Wu Q, Li CF, Steinmetz A, Conservation and sustainable use of medicinal plants: problems, progress, and prospects. Chin Med., 2016; 11(1): 37: 1-10. 
FARMACIA, 2020, Vol. 68, 2

12. Dorant E, van den Brandt PA, Goldbohm RA, A prospective cohort study on Allium vegetable consumption, garlic supplement use, and the risk of lung carcinoma in The Netherlands. Cancer Res., 1994; 54(23): 61486153.

13. Eldin IMT, Ahmed EM, Hm AE, Preliminary study of the clinical hypoglycemic effects of Allium cepa (red onion) in type 1 and type 2 diabetic patients. Environ Health Insights, 2010; 4: 71-77.

14. Fritsch RM, Abbasi M, A taxonomic review of Allium subg. Melanocrommyum in Iran, Leibniz-Institut für Pflanzengenetik und Kulturpflanzenforschung, Gatersleben (IPK), 2013.

15. Ha AW, Ying T, Kim WK, The effects of black garlic (Allium satvium) extracts on lipid metabolism in rats fed a high fat diet. Nutr Res Pract., 2015; 9(1): 30-36.

16. Harris JC, Cottrell SL, Plummer S, Lloyd D, Antimicrobial properties of Allium satvium (garlic). Appl Microbiol Biotechnol., 2001; 57(3): 282-286.

17. Hosseini S, Go R, Cytogenetic study of some Allium species (subgenus Allium and Melanocrommyum) in Iran. Cytologia, 2010; 75(1): 99-108.

18. Jafari S, Hassandokht MR, Taheri M, Kashi A, Genetic diversity and taxonomic studies of Allium akaka and A. elburzense native to Iran using morphological characters. J Hort Res., 2017; 25(1): 99-115.

19. Jang JY, Lee MJ, You BR, Jin JS, Lee SH, Yun YR, Kim HJ, Allium hookeri root extract exerts antiinflammatory effects by nuclear factor-kB downregulation in lipopolysaccharide-induced RAW264.7 cells. BMC Complement Altern Med., 2017; 17(1): 126-134.

20. Khodadadi S, Nejadsattari T, Naqinezhad A, Ebrahimzadeh MA, Diversity in antioxidant properties and mineral contents of Allium paradoxum in the Hyrcanian forests, Northern Iran. Biodiversitas, 2015; 16(2): 281-287.

21. Koncic MZ, Jug M, Antioxidant and bioadhesive properties of onions (Allium L., Alliaceae) processed under acidic conditions. Int J Food Prop., 2011; 14(1): 92-101.

22. Kyung KH, Antimicrobial properties of Allium species. Curr Opin Biotechnol., 2012; 23(2): 142-147.

23. Liguori L, Califano R, Albanese D, Raimo F, Crescitelli A, Di Matteo M, Chemical composition and antioxidant properties of five white onion (Allium cepa $\mathrm{L}$.) landraces. J Food Qual., 2017; 2017: 1-9.

24. Londhe VP, Gavasane AT, Nipate SS, Bandawane DD, Chaudhari PD, Role of garlic (Allium sativum) in various diseases-an overview. J Pharm Res Opin., 2011; 1(4): 129-134.
25. Mostafa HHA, Haiping W, Xinyan L, Xixiang L, Impact of genetic factor and geographical location on allicin content of garlic (Allium sativum) germplasm from Egypt and China. Int J Agric Biol., 2015; 17(1): 156162.

26. Parvu AE, Catoi F, Deelawar S, Sarup D, Parvu M, Anti-Inflammatory Effect of Allium ursinum. Not Sci Biol., 2014; 6(1): 20-26.

27. Patra S, Nithya S, Srinithya B, Meenakshi SM, Review of medicinal plants for anti-obesity activity. Transl Biomed., 2015; 6(3): 1-22.

28. Rahman K, Lowe GM, Garlic and cardiovascular disease: a critical review. J Nutr., 2006; 136(3): 736S$740 \mathrm{~S}$.

29. Rahul K, Kundan SB, Nirmal S, Richa S, Ameliorative effect of Allium cepa on oxidative stress and neuronal damage after ischemia and reperfusion-induced cerebral injury. J Appl Pharm., 2014; 6(4): 432-445.

30. Ro JY, Ryu JH, Park HJ, Cho HJ, Onion (Allium cepa L.) peel extract has anti-platelet effects in rat platelets. Springerplus, 2015; 4(1): 17-24.

31. Setiawan VW, Yu GP, Lu QY, Lu ML, Yu SZ, Mu L, Zhang JG, Kurtz RC, Cai L, Hsieh CC, Allium vegetables and stomach cancer risk in China. Asian Pac J Cancer Prev., 2005; 6(3): 387-395.

32. Sung YY, Kim SH, Yoo BW, Kim HK, The nutritional composition and anti-obesity effects of an herbal mixed extract containing Allium fistulosum and Viola mandshurica in high-fat-diet-induced obese mice. BMC Complement Altern Med., 2015; 15(1): 370-378.

33. Wang H, Li X, Shen D, Oiu Y, Song J, Diversity evaluation of morphological traits and allicin content in garlic (Allium sativum L.) from China. Euphytica, 2014; 198(2): 243-254.

34. WHO, www.who.int/mediacentre/factsheets/fs310/ en/2015.

35. Yang MH, Kim NH, Heo JD, Rho JR, Ock KJ, Shin EC, Jeong EJ, Comparative evaluation of sulfur compounds contents and antiobesity properties of Allium hookeri prepared by different drying methods. Evid Based Complement Alternat Med., 2017; 2017: 1-10.

36. Zahedi B, Kashi AK, Zamani Z, Mosahebi GH, Hassani M, Evaluation of Iranian garlic (Allium sativum L.) genotype using multivariate analysis methods based on morphological characters. Biotechnol., 2007; 6(3): 353-356.

37. Zeng Y, Li Y, Yang J, Pu X, Du J, Yang X, Yang T, Yang S, Therapeutic role of functional components in Alliums for preventive chronic disease in human being. Evid Based Complement Alternat Med., 2017; 2017: 1-13. 